\author{
Ks. Marek Jodkowski \\ https://orcid.org/0000-0001-9793-9935 \\ Wydział Teologii Uniwersytetu Warmińsko-Mazurskiego w Olsztynie
}

\title{
Pertraktacje na temat statusu Kościoła katolickiego w Okręgu Kłajpedy w latach 1923-1926
}

\begin{abstract}
Abstrakt: Od zajęcia przez Litwinów Okręgu Kłajpedy w 1923 r. status prawny Kościoła katolickiego na tym obszarze zyskał charakter polityczny. Pertraktacje między Stolicą Apostolską, Niemcami i Litwą dotyczyły utworzenia delegatury podległej biskupowi warmińskiemu bądź odrębnej diecezji z biskupem niemieckim na jej czele, a nawet erygowania wikariatu apostolskiego w tym regionie. Ostatecznie Pius XI w bulli „Lituanorum gente” z 4 IV 1926 r. utworzył udzielną prałaturę kłajpedzką z biskupem telszańskim na czele.
\end{abstract}

Słowa kluczowe: diecezja warmińska, Litwa, Niemcy, Okręg Kłajpedy, udzielna prałatura kłajpedzka.

Abstract: After the Lithuanians seized the Klaipeda District in 1923, the legal status of the Catholic Church in this area gained a political character. The negotiations between the Holy See, Germany and Lithuania concerned the establishment of a delegacy subordinate to the Warmian bishop or a separate diocese with the German bishop at its head, or even the erection of an apostolic vicariate in this region. Ultimately, Pope Pius XI by his bull Lituanorum gente of 4 April 1926 created a separate Klaipeda's prelature with the bishop of Telsche.

Key w or d s: Diocese of Warmia, Lithuania, Germany, Klaipeda Region (Memelland), free prelature of Klaipeda. 


\section{Wstęp}

Historiografia Okręgu Kłajpedy doczekała się licznych publikacji wydanych w językach litewskim i niemieckim ${ }^{1}$. Wielu historyków zajmowało się przy tym dziejami dominującego wyznania na tym obszarze, czyli ewangelicyzmu. Badania dotyczące katolicyzmu nie cieszyły się dotychczas zbyt dużym zainteresowaniem. Prawdopodobnie było to spowodowane niewielką liczbą członków tego wyznania zamieszkujacych wspomniane tereny. Nieoceniony tekst na temat podporządkowania tamtejszych parafii zwierzchniej władzy kościelnej na Litwie wyszedł spod pióra Arūnasa Streikusa 2 . Nie do przecenienia pozostaje również studium ks. Andrzeja Kopiczki, dotyczące funkcjonowania tej konfesji w Okręgu Kłajpedy ${ }^{3}$, w którym przybliża on wiadomości na temat udziału diecezji warmińskiej w tworzeniu placówek duszpasterskich, a także w obsadzie tamtejszych urzędów kościelnych. Przytoczone opracowania nie wyczerpuja jednak szeregu zagadnień związanych z problematyką Kościoła katolickiego w Okręgu Kłajpedy w latach dwudziestych XX w., a zwłaszcza określeniem jego statusu prawnego. Żeby uzupełnić te informacje, warto przeprowadzić analizę rzadko dotychczas wykorzystywanych materiałów archiwalnych zdeponowanych w Bundesarchiv w Berlinie.

\section{Tło historyczno-polityczne}

W czasie konferencji paryskiej, zorganizowanej po I wojnie światowej, zadecydowano, że Okręg Kłajpedy zostanie wyłączony spod jurysdykcji niemieckiej i oddany pod tymczasowy zarzad wielkich mocarstw ${ }^{4}$. Stosowny zapis dotyczacy statusu prawnego tego obszaru zawarto w art. 99 traktatu wersalskiego. $\mathrm{Z}$ kolei art. 28 regulował granice Prus Wschodnich, wydzielając z nich Okręg Kłajpedy. Postanowienia traktatu weszły w życie 10 I 1920 r., a miesiąc później ostatni niemieccy żołnierze opuścili opisywane tereny, podczas gdy angielskie i francuskie torpedowce zawitały do tamtejszego portu. 15 lutego tego roku niemiecki komisarz Georg Franz Lambsdorff przekazał oficjalnie Okręg Kłajpedy francuskiemu gen. Dominique Odry'emu ${ }^{5}$.

${ }^{1}$ Zob. zwłaszcza: J. Tauber, Das Memelgebiet (1919-1945) in der deutschen und litauischen Historiografie nach 1945, „Nordost-Archiv. Zeitschrift für Regionalgeschichte” (Neue Folge) 2001, t. X, s. 11-44.

2 A. Streikus, Die Integration der memelländischen Katholiken in die Kirchenprovinz Litauen 1926-1939, „Annaberger Annalen” 2013, nr 21, s. 100-127.

${ }^{3}$ A. Kopiczko, Die katholische Kirche in Memelland (1923-1939), „Acta Historica Universitatis Klaipedensis" 2015, t. XXX, s. 101-125.

${ }^{4}$ Idem, Duchowieństwo katolickie diecezji warmińskiej w latach 1821-1945, cz. 1: Studium prozopograficzne, Olsztyn 2004, s. 246; S. Mikulicz, Kłajpeda w polityce europejskiej 1918-1939, Warszawa 1976, s. 38.

${ }^{5}$ A. Kopiczko, Die katholische Kirche in Memelland..., s. 103; S. Mikulicz, op. cit., s. 38. 
Do przełomowych wydarzeń w historii Okręgu Kłajpedy należało niewątpliwie żądanie parlamentu litewskiego z 11 XI $1921 \mathrm{r}$. dotyczace przyłączenia tego obszaru do Litwy. Gwarantowano przy tym jego autonomię w sprawach gospodarczych, socjalnych, prawnych, kształcenia, kultury i religii. Ostatecznie w połowie stycznia $1923 \mathrm{r}$. Litwini wywołali powstanie zbrojne i zajęli Okręg Kłajpedy, a oddziały francuskie opuściły ten obszar. Rok później, czyli $8 \mathrm{~V}$ 1924 r. Litwini podpisali umowę, zgodnie z którą Kraj Kłajpedzki stał się suwerenną czesścią Litwy na prawach autonomii ${ }^{6}$.

\section{Nadanie nowego statusu Kościołowi katolickiemu w Okręgu Kłajpedy}

W 1923 r. w Okręgu Kłajpedy znajdowały się następujące katolickie placówki duszpasterskie: parafia w Kłajpedzie (ok. 2,5 tys. wiernych), Robkojen (ok. 1 tys.), Szyłokarczmie (ok. 1,5 tys.) i parafia misyjna w Wieszwile (ok. 600). Stanowiły one północny kraniec diecezji warmińskiej. Pozostałe parafie dekanatu litewskiego, do którego należał Okręg Kłajpedy, a więc Bilderweitschen, Schyłgały i Tylża podlegały jurysdykcji Prus Wschodnich? Biskup warmiński Augustyn Bludau odnotował tego roku, że w czasie wizytacji odbywającej się kilka miesięcy wcześniej w parafiach Nadniemna przekonał się o ich na wskroś niemieckim charakterze. Większość nielicznych Litwinów, konstatował hierarcha, przeważnie przybyszów, rozumiała język niemiecki. Wszyscy katoliccy duchowni, łącznie z wikariuszem w Kłajpedzie, nauczyli się języka litewskiego (a konkretnie mówionego na tamtym obszarze dialektu żmudzkiego) w stopniu odpowiadającym podejmowanym przez nich zadaniom. Biskup twierdził nawet, że proboszczowie z Kłajpedy i Szyłokarczmy mówili znakomicie po litewsku ${ }^{8}$.

W kwietniu bądź maju 1923 r. dziekan z Kłajpedy, ks. Albert Dannelautzki informował biskupa warmińskiego, że władze Litwy dążą do przyłączenia Kościoła katolickiego w Okręgu Kłajpedy do diecezji żmudzkiej ze stolica w Kownie. Przez to zamierzano umocnić litewskość tych obszarów. Duchowieństwo tej diecezji znało język niemiecki w bardzo ograniczonym zakresie. Ponadto bp Bludau uważał, że ich litewski nie będzie zrozumiały przez mieszkańców Okręgu Kłajpedy, którzy posługują się dialektem żmudzkim. Hierarcha wspominał, że w Kłajpedzie zamieszkał litewski kapelan wojskowy, któremu udzielił on pozwolenia na spowiadanie ludności cywilnej. Niestety,

\footnotetext{
${ }^{6}$ A. Kopiczko, Die katholische Kirche in Memelland..., s. 103; S. Mikulicz, op. cit., s. 44, 72-73, 115-116; J. Ochmański, Historia Litwy, wyd. 2 popr. i uzup., Wrocław 1982, s. 318-319.

7 Bundesarchiv Berlin (dalej: BAB), R 5101/21807, bp Bludau do [ks. Johanna Steinmanna], 9 V 1923, (kopia), k. 186; por. A. Streikus, op. cit., s. 100; zob. też: Politisches Archiv des Auswärtigen Amts (Berlin) (dalej: PA AA), R 62224, ks. Dannelautzki do Konsulatu Generalnego Niemiec w Kłajpedzie, 22 II 1923.

${ }^{8}$ BAB, R 5101/21807, bp Bludau do [ks. Johanna Steinmanna], 9 V 1923, (kopia), k. 186.
} 
jego język nie był komunikatywny dla tamtejszych Litwinów. Biskup warmiński konstatował, że katolicy tego obszaru niechętnie zatem zaakceptowaliby zmiany w statusie kłajpedzkiego Kościoła ${ }^{9}$.

W tym samym czasie administrator apostolski Wolnego Miasta Gdańska bp Edward O'Rourke informował Konsulat Generalny Niemiec w Gdańsku o planach utworzenia na Litwie czterech nowych diecezji. Z związku z tym dalsze utrzymanie Okręgu Kłajpedy pod jurysdykcją biskupa warmińskiego wydawało się niemożliwe. Żeby zaradzić negatywnym konsekwencjom nowego porządku prawnego, bp O'Rourke zaprezentował koncepcję utworzenia specjalnej biskupiej administracji dla tego obszaru, która spoczywałaby w rękach miejscowych niemieckich księży. Jej pomysłodawcą był prawdopodobnie bp Bludau. Biskup O’Rourke proponował również, żeby kształcić kłajpedzkich księży w Seminarium Duchownym w Braniewie ${ }^{10}$.

W obliczu niebezpieczeństwa dalszej lituanizacji Okręgu Kłajpedy Ministerstwo Spraw Zagranicznych (MSZ) Niemiec podjęło kroki dyplomatyczne mające na celu utrzymanie tamtejszych czterech katolickich parafii w granicach diecezji warmińskiej. Równocześnie zagwarantowano subwencje proboszczowskie oraz możliwość kształcenia księży w języku litewskim na potrzeby kłajpedzkich placówek duszpasterskich ${ }^{11}$.

Niemiecki minister nauki, sztuki i edukacji 18 V 1923 r. poparł ideę zaprezentowana przez bpa O'Rourke, dotycząca utworzenia terytorialnej jednostki kościelnej w Okręgu Kłajpedy, zależnej od biskupa warmińskiego. Minister zauważył przy tym, że ludność tego obszaru w dominującym stopniu deklaruje przynależność do Kościoła ewangelickiego, a na dodatek identyfikuje się z narodem niemieckim. Gdyby katolicy optowali za odłączeniem Okręgu Kłajpedy od Niemiec bądź do niego doprowadzili, zostałoby to niekorzystnie ocenione $\mathrm{w}$ niekatolickich środowiskach ${ }^{12}$.

Na początku października 1923 r. MSZ Niemiec rozpowszechniało informacje przekazane przez ks. Dannelautzkiego z Kłajpedy, że wzmogły się starania Litwinów o przyłączenie katolickich parafii z Okręgu Kłajpedy do diecezji położonej na Litwie. Te dążenia popierał szczególnie bp Franciszek Karewicz z Kowna. Zabiegał on, aby te parafie weszły w skład diecezji żmudzkiej bądź jednej z mających powstać na terenie Litwy. Bezpośrednimi tego skutkami byłyby wyeliminowanie niemieckiego duchowieństwa z posługi duszpasterskiej oraz narzucenie języka litewskiego w nabożeństwach, jak

\footnotetext{
${ }_{9}$ Ibidem, bp Bludau do [ks. Johanna Steinmanna], 9 V 1923, (kopia), k. 187; zob. też: PA AA, R 62224, ks. Dannelautzki do Konsulatu Generalnego Niemiec w Kłajpedzie, 22 II 1923.

${ }_{10}$ BAB, R 5101/21807, Konsulat Generalny Niemiec w Gdańsku do Ministerstwa Spraw Zagranicznych Niemiec, 13 IV 1923, k. 180.

${ }^{11}$ Ibidem, Ministerstwo Spraw Zagranicznych Niemiec do Ministerstwa Nauki, Sztuki i Edukacji, 30 IV 1923, k. 180v.

${ }^{12}$ Ibidem, minister nauki, sztuki i edukacji do Ministerstwa Spraw Zagranicznych Niemiec, 18 V 1923, k. 181.
} 
również w nauczaniu szkolnym. W ten sposób osłabiono by niemieckość Nadniemna $^{13}$. Oczywiście z wcześniejszych deklaracji duchowieństwa katolickiego wynikała chęć dalszej przynależności do diecezji warmińskiej. Gdyby nie udało się utrzymać dotychczasowego statusu kościelnego Okręgu Kłajpedy, jedynym rozwiązaniem według ks. Dannelautzkiego miało być utworzenie samodzielnej delegatury podległej biskupowi warmińskiemu ${ }^{14}$. Konsulat Generalny Niemiec w Kłajpedzie popierał to rozwiązanie. Ksiądz Dannelautzki poufnie informował jego przedstawiciela, że biskup warmiński nie zdaje sobie sprawy z konsekwencji przyłączenia Nadniemna do diecezji litewskiej i dlatego tych kwestii nie traktuje priorytetowo ${ }^{15}$.

Sprawa jurysdykcji kościelnej obejmujacej Okręg Kłajpedy nabrała zatem charakteru politycznego. Niemieckie władze państwowe próbowały wykorzystać nadarzająca się okazję, aby zyskać przychylność bpa Bludaua. Na początku sierpnia 1923 r. rozważały pokrycie części kosztów planowanej przez niego na październik podróży do Rzymu ${ }^{16}$. Przedstawiciele diecezji warmińskiej dyskretnie jednak wskazywali, aby państwo sfinansowało wyjazd księdzu, który będzie towarzyszył biskupowi w drodze do Wiecznego Miasta. W ten sposób ordynariusz nie czułby się bezpośrednio zobligowany do okazania wdzięczności. Uległość wobec władz państwowych mogła jednak skutkować ich presja wywierana na hierarsze $\mathrm{w}$ sprawie kościelnej jurysdykcji nad Okręgiem Kłajpedy ${ }^{17}$. W listopadzie 1923 r. MSZ Niemiec deklarowało, że weźmie na siebie koszty podróży do Rzymu osoby towarzyszącej biskupowi warmińskiemu ${ }^{18}$, o czym ordynariusz dowiedział się z listu przesłanego 17 XII 1923 r. $^{19}$

Na początku 1924 r. Stolica Apostolska obwieściła ambasadorowi Niemiec, że nie podjęto żadnych działań zmierzających do korekty granic diecezji warmińskiej. Kongregacja Konsystorialna mogła powziać decyzję w tej sprawie po uprzednim zasięgnięciu opinii Sekretariatu Stanu. Urząd ten analizował, czy postulowana zmiana nie narusza również interesów politycznych. Uprzedzając tę procedurę, ambasador Niemiec zakomunikował przedstawicielowi Watykanu, że zmiana przynależności kościelnej Okręgu Kłajpedy spotkałaby się ze stosowną reakcją Niemiec. Dyplomata przypuszczał, że rząd litewski

${ }^{13}$ Ibidem, Ministerstwo Spraw Zagranicznych Niemiec do Ministerstwa Nauki, Sztuki i Edukacji, 2 X 1923, k. 197.

${ }^{14}$ Ibidem.

15 Ibidem, k. 197-197v.

${ }^{16}$ Ibidem, die Akten Generalia II, k. 195; zob. też: ibidem, bp Bludau do [ks. Johanna Steinmanna], 9 V 1923, (kopia), k. 188; por. A. Kopiczko, Die katholische Kirche in Memelland..., s. 104.

${ }_{17}$ BAB, R 5101/21807, Ministerstwo Spraw Zagranicznych Niemiec, 5 X 1923, k. 198v.

${ }^{18}$ Ibidem, Ministerstwo Spraw Zagranicznych Niemiec do Ministerstwa Nauki, Sztuki i Edukacji, 24 XI 1923, k. 201.

${ }^{19}$ Ibidem, Ministerstwo Nauki, Sztuki i Edukacji do bpa Bludaua, 17 XII 1923, k. 204v. 
nie wyszedł jeszcze z taką inicjatywa. Gdyby jednak tak się stało, Niemcy miały optować za utworzeniem samodzielnej delegatury podległej biskupowi warmińskiemu ${ }^{20}$.

Niemiecki minister nauki, sztuki i edukacji 4 III 1924 r. ponawiał prośbę skierowaną do biskupa warmińskiego, żeby zdecydowanie sprzeciwiał się zmianie statusu kościelnego Okręgu Kłajpedy, lobbując za utrzymaniem tych ziem w granicach diecezji warmińskiej. Sugerował także ordynariuszowi, aby dzielił się z nim wszystkimi uzyskanymi informacjami związanymi z ta sprawa $^{21}$. W odpowiedzi biskup warmiński tłumaczył się przede wszystkim z odroczenia podróży do Rzymu, co wynikało najprawdopodobniej z jego przezorności. W $1923 \mathrm{r}$. jej nie zrealizował, ponieważ zachorował wikariusz generalny, który miał kierować diecezją podczas nieobecności ordynariusza. Ponadto nie udało się mu zgromadzić pieniędzy na tak daleką wyprawę. Również w 1924 r. wydawała się niemożliwa, ponieważ zgromadzony przez niego kapitał finansowy, który ulokował w papierach wartościowych, stracił całkowicie swoją wartość. Przychody biskupa wynosiły wówczas jedna czwartą jego rocznego uposażenia sprzed I wojny światowej ${ }^{22}$. Ordynariusz warmiński poinformował również ministerstwo, że zrelacjonował dokładnie nuncjuszowi w Monachium, jak również konsultorowi Ambasady Niemiec przy Stolicy Apostolskiej ks. prałatowi Johannowi Steinmannowi sytuację Kościoła katolickiego w Okręgu Kłajpedy. Ten ostatni tłumaczył, że nie powiadomiono Stolicy Apostolskiej o dążeniach do odłączenia tamtejszych parafii katolickich i podporządkowania ich diecezji żmudzkiej. Obiecał on także, że skontaktuje się z biskupem warmińskim, jak tylko sprawą tą zajmą się urzędnicy papiescy. Biskup Bludau konstatował, że jeśli zostanie utrzymana autonomia Okręgu Kłajpedy, wówczas obawy zwiąane z przyłączeniem tamtejszych parafii do diecezji litewskiej będą nieuzasadnione. Jeśli jednak władze państwowe wprowadzą do nauczania szkolnego język litewski, a nie dialekt żmudzki, wówczas księża warmińscy, którzy z trudem opanowali dialekt, staną wobec dylematu akceptacji tego rodzaju rozporządzeń. Zdaniem ordynariusza większość członków tamtejszych parafii katolickich posługiwała się na co dzień językiem niemieckim ${ }^{23}$.

Utworzenie kościelnej delegatury na Okręg Kłajpedy wydawało się biskupowi warmińskiemu zbyt kosztowne. Przypominał on, że wcześniej zastanawiano się nad erygowaniem nowej diecezji na tym obszarze, z niemieckim biskupem, który władałby językiem litewskim. Zostałaby ona dołączona do diecezji żmudzkiej, zapewne na zasadzie podporządkowania metropolii.

\footnotetext{
${ }^{20}$ Ibidem, Ambasada Niemiec przy Stolicy Apostolskiej do Ministerstwa Spraw Zagranicznych Niemiec, 12 I 1924, k. 205.

${ }^{21}$ Ibidem, Ministerstwo Nauki, Sztuki i Edukacji do bpa Bludaua, 4 III 1924, k. 206-206v.

${ }^{22}$ Ibidem, bp Bludau do ministra nauki, sztuki i edukacji, 14 III 1924, k. 207.

${ }^{23}$ Ibidem, k. 207-207v.
} 
Ordynariusz wątpił jednak w realizację tak śmiałych planów. Zapewniał, że w interesie diecezji warmińskiej pozostaje zachowanie Nadniemna w jej granicach. W tym czasie ustanowił nawet drugiego wikariusza w Kłajpedzie, ponieważ kłajpedzki dyrektoriat zagwarantował mu odpowiednie przychody. Miał on uczyć się na miejscu języka litewskiego. Mieszkajacy w tym mieście kapelan wojskowy, pochodzacy z diecezji żmudzkiej, nie posługiwał z kolei wśród ludności cywilnej ${ }^{24}$.

W liście do konsultora Ambasady Niemiec przy Stolicy Apostolskiej ks. prałata Steinmanna z 26 IV 1924 r. bp Bludau informował, że nowy luterański komisarz Viktor Gailus (lit. Viktoras Gailius) wszelkimi sposobami dąży do wyegzekwowania niezależności Okręgu Kłajpedy od Ewangelickiej Naczelnej Rady Kościelnej w Berlinie. Z kolei były przedstawiciel dyplomatyczny Litwy we Włoszech, Jurgis Šaulys zabiegał o odłączenie kłajpedzkich parafii katolickich od diecezji warmińskiej i podporządkowanie ich diecezji żmudzkiej. Biskup warmiński odbył ponadto rozmowę z senatorem Wolnego Miasta Gdańska Hermannem Strunkiem, który wyraził swoją dezaprobatę regulacji statusu Kościoła katolickiego w tym autonomicznym mieście. Administracje apostolska powołano w nim bez uprzedniego zasięgnięcia opinii biskupów warmińskiego i chełmińskiego oraz duchowieństwa Wolnego Miasta Gdańska. Uważał on, że jeśliby w podobny sposób uregulowano stosunki kościelne w Okręgu Kłajpedy, zgodnie zresztą z życzeniem Litwy, odbiłoby się to niekorzystnie na Kościele katolickim. Biskup Bludau wskazał przy tym na warmińskich księży, którzy rzekomo deklarowali, że opuściliby wówczas zarządzane przez nich kłajpedzkie parafie i wróciliby na Warmię. Być może odebrano by im nawet pozwolenie na pobyt w tym autonomicznym regionie, gdyby nie opowiedzieliby się za Okręgiem Kłajpedy bądź Litwą. Niemieckojęzyczni parafianie pozostaliby zatem bez duszpasterzy. Z kolei litewscy księża dążyliby niechybnie do wyeliminowania języka niemieckiego ze szkół i kościołów Nadniemna ${ }^{25}$.

Ksiądz dziekan Dannelautzki w połowie kwietnia 1924 r. powiadamiał biskupa warmińskiego o nikłych nadziejach związanych z utrzymaniem politycznej niezależności Okręgu Kłajpedy. Należało się zatem spodziewać, że w konsekwencji obszar ten zostanie włączony do diecezji litewskiej. Kłajpedzki dyrektoriat zażądał w tym czasie od tamtejszego Kościoła ewangelickiego pełnego uniezależnienia od Ewangelickiej Naczelnej Rady Kościelnej w Berlinie. Ponieważ władze ewangelickie nie uznały zarówno tego postulatu, jak i nowo ustanowionego komisarza ds. kościelnych, wstrzymano tamtejszemu

${ }^{24}$ Ibidem, k. 207v.

${ }^{25}$ Ibidem, bp Bludau do [ks. Johanna Steinmanna], 26 IV 1924, (kopia), k. 209-211; zob. też: A. Hermann, Die Evangelische Kirche im Memelland des 20. Jahrhundert, „Nordost-Archiv. Zeitschrift für Regionalgeschichte" (Neue Folge) 2001, t. X, s. 348-349; H.A. Kurschat, Das Buch vom Memelland. Heimatkunde eines deutschen Grenzlandes, Oldenburg 1968, s. 476. 
duchowieństwu wypłate pensji ${ }^{26}$. Dziekan Dannelautzki pisał również, że Šaulys zaplanował po Świętach Wielkanocnych podróż do Stolicy Apostolskiej, aby lobbować za separacją katolickich parafii w Okręgu Kłajpedy. Zdaniem duchownego utrzymanie tego obszaru w granicach diecezji warmińskiej zależało od interwencji biskupa warmińskiego w Rzymie. Gdyby jednak nie udało się tego osiagnać, należało nadać temu obszarowi określoną kościelna niezależność, np. poprzez ustanowienie komisarza biskupiego będącego przedstawicielem lokalnego duchowieństwa. Podlegałby on ordynariuszowi warmińskiemu. Takie rozwiązanie byłoby pożądane, ponieważ dyrektoriat nie dopuszczał do pertraktacji z obcym podmiotem prawnym, np. z władzami kościelnymi we Fromborku. Szereg zaś spraw wymagał aprobaty biskupa warmińskiego (np. ustalanie pensji duchowieństwa kłajpedzkiego ${ }^{27}$. Dzięki prerogatywom przyznanym komisarzowi biskupiemu podważono by większość argumentów za inkorporacją parafii Nadniemna do diecezji na Litwie. Dziekan kłajpedzki odnotował również, że legat papieski miał zamiar przyjechać do Okręgu Kłajpedy na Święta Wielkanocne 1924 r. Ksiądz Dannelautzki prosił go jednak o odroczenie tego terminu, ponieważ w tym czasie nie mógłby go podjąć. Ponadto oczekiwał od biskupa warmińskiego wskazówek co do postępowania z papieskim wysłannikiem. Konstatował przy okazji, że gdyby doszło do przyłączenia parafii katolickich do diecezji litewskiej, wówczas kłajpedzkie duchowieństwo posługujące w parafiach nie otrzymywałoby państwowej pensji. Litwa bowiem nie wypłacała duszpasterzom tego rodzaju świadczeń28 ${ }^{28}$.

List bpa Bludaua na temat parafii katolickich Okręgu Kłajpedy został przekazany do Sekretariatu Stanu z intencja zablokowania wszelkich zmian dotyczacych kościelnej przynależności tego obszaru. Do 23 V 1924 r. Litwa nie wystapiła z żadnymi postulatami do Stolicy Apostolskiej odnoszacymi się do Nadniemna. Nie poinformowano jej również o planowanej podróży Šaulysa ${ }^{29}$. Ze względu na stosunek dyrektoriatu do władz diecezji warmińskiej Ambasada Niemiec przy Stolicy Apostolskiej powiadomiła Sekretariat Stanu, że dopuszcza ustanowienie dziekana kłajpedzkiego katolickim komisarzem kościelnym. Miałby on zabiegać w dyrektoriacie o finansowe i administracyjne sprawy Kościoła katolickiego ${ }^{30}$. Ordynariusz warmiński 23 V 1924 r. ustanowił zatem dziekana kłajpedzkiego komisarzem biskupim, zlecając mu zadanie nadzorowania spraw kościelnych zależnych od dyrektoriatu, a dotyczących katolickich szkół i parafii ${ }^{31}$.

\footnotetext{
${ }^{26}$ Na podstawie umowy zawartej 31 VII 1925 r. przez Ewangelicką Naczelną Radę Kościelną w Berlinie oraz rząd litewski powołano w Okręgu Kłajpedy samodzielną prowincję kościelna Pruskiego Kościoła Ewangelickiego, która formalnie odłączyła się od prowincji kościelnej w Prusach Wschodnich. Zob. A. Streikus, op. cit., s. 104.

${ }^{27}$ BAB, R 5101/21807, ks. Dannelautzki do bpa Bludaua, 15 IV 1924, (kopia), k. 213.

${ }^{28}$ Ibidem, k. 213-214.

${ }^{29}$ Ibidem, ks. Steinmann do bpa Bludaua, 23 V 1924, (kopia), k. 215.

${ }^{30}$ Ibidem, k. 216.

${ }^{31}$ Ibidem, bp Bludau do ministra nauki, sztuki i edukacji, 8 VIII 1924, k. 219.
} 
W tym czasie pojawiały się opinie, że planowana cyrkumskrypcja kościelna w Polsce i Wolnym Mieście Gdańsku pociagnie za sobą korektę granic wschodnich diecezji pruskich z uwagi na nowy podział polityczny. Niemiecki minister nauki, sztuki i edukacji dementował te przypuszczenia, wskazując na konieczność uprzedniego porozumienia Stolicy Apostolskiej z Republika Weimarska. W czasie konferencji paryskiej doprowadzono bowiem do zmian politycznych, które naruszyły zapisy zawarte w bulli „De salute animarum" z $1821 \mathrm{r}$. Przede wszystkim ustanowiono administratury apostolskie w Gdańsku, Tucznie i Katowicach. Pozostające w Prusach skrawki diecezji chełmińskiej powierzono pieczy biskupa warmińskiego. Dyplomacja niemiecka z rezerwa podchodziła do nowej regulacji stosunków kościelnych na niegdyś pruskich, a następnie polskich obszarach. Pertraktacje na ten temat, mające zresztą stanowić treść konkordatu, odroczono ${ }^{32}$.

W 1925 r. biskup warmiński opowiadał się za dotychczasową przynależnością Kościoła katolickiego w Kraju Kłajpedzkim do diecezji warmińskiej. Miał wyrażać przy tym wolę tamtejszych katolików. Z kolei księża domagali się respektowania ich przywilejów na równi z duchowieństwem mieszkającym w Niemczech. Konsulat Generalny Niemiec w Okręgu Kłajpedy deklarował, że przychyla się ku wszelkiego rodzaju działaniom mającym na celu utrzymanie tych ziem w łączności z Republiką Weimarską. Z tego względu wspierano inicjatywy tamtejszych katolików, którzy zarówno u biskupa warmińskiego, jak i w urzędach Stolicy Apostolskiej protestowali przeciwko włączeniu parafii Nadniemna do diecezji żmudzkiej ${ }^{33}$. Warto wspomnieć zwłaszcza o jednej z nich. Otóż syn właściciela kłajpedzkiej fabryki celulozy o nazwisku Vorbeck, który kształcił się wcześniej w klasztorze benedyktyńskim Ettal, zwrócił się z prośba do jednego z najbardziej wpływowych stronników papieskich w Bawarii, barona Theodora von Cramer-Kletta z Hohenaschau, aby zainicjował kolejne rozmowy w Watykanie na temat niemieckich katolików w Okręgu Kłajpedy ${ }^{34}$. Baron odpowiedział, że może będzie miał sposobność rychłego przedłożenia tej sprawy w Sekretariacie Stanu, a nawet samemu papieżowi. Zapraszał Vorbecka do wcześniejszego przyjazdu do Monachium, aby szczegółowo omówić te kwestie. Sugerował również, żeby biskup warmiński bądź kuria diecezjalna wystosowali memoriał do Stolicy Apostolskiej, ponieważ zazwyczaj żąda ona wyjaśnień od biskupa miejscowego ${ }^{35}$. Na spotkaniu w Monachium Vorbeck opisał szczegółowo stosunki polityczne panujące w Okręgu Kłajpedy, a także scharakteryzował duchowieństwo litewskie. Z kolei zarząd kościelny parafii w Kłajpedzie, za przyzwoleniem tamtejszego konsula niemieckiego,

\footnotetext{
${ }^{32}$ Ibidem, Ministerstwo Nauki, Sztuki i Edukacji, 14 VIII 1925, k. 222.

${ }^{33}$ Ibidem, Konsulat Generalny Niemiec w Kłajpedzie do Ministerstwa Spraw Zagranicznych Niemiec, 14 V 1925, k. 223-225.

${ }^{34}$ Ibidem, k. 225.

${ }^{35}$ Ibidem, Cramer-Klett do Vorbecka, 15 IV 1925, k. 229.
} 
oddelegował swoich przedstawicieli do biskupa warmińskiego, wśród których znalazł się również wicekonsul Adolf Windecker ${ }^{36}$.

Reprezentanci kłajpedzkiej parafii chcieli zorientować się, jakie jest stanowisko biskupa względem spraw kościelnych w Okręgu Kłajpedy, a także wskazać mu na naglace, ich zdaniem, niebezpieczeństwo ze strony Litwinów. Ponadto zamierzali wręczyć ordynariuszowi memoriał adresowany do przebywającego w Rzymie barona Cramer-Kletta. 8 V 1925 r. bp Bludau, niepoinformowany o celu przyjazdu delegacji, przyją ją dość chłodno. Trwająca ok. półtorej godziny prywatna audiencja umożliwiła jednak Vorbeckowi seniorowi prezentację problematyki kościelnej w Okręgu Kłajpedy. Konstatował on, że należy liczyć się z przyłączeniem tego obszaru do diecezji żmudzkiej. Wynikało to z przedłożenia przez stronę litewską swoich racji w Watykanie. Stolica Apostolska nie chciała polaryzować społeczeństwa litewskiego. Już raz skończyły się fiaskiem dążenia Litwinów, aby utrzymać w swoich granicach kościelnych obszar Wilna i okolic. Przedstawiciel delegacji podkreślał stanowczo, że podporządkowanie parafii katolickich w Okręgu Kłajpedy diecezji litewskiej spotkałoby się ze zdecydowanym sprzeciwem niemieckich katolików. Jeśliby jednak Stolica Apostolska uznała racje Litwy, wówczas należało się spodziewać rezygnacji niemieckich katolików z życia kościelnego na opisywanym obszarze ${ }^{37}$.

Biskup Bludau zapewniał, że pozostaje w kontakcie zarówno z nuncjuszem w Monachium, jak i ks. prałatem Steinmannem w Rzymie. Ponadto przebywał w Wiecznym Mieście pewien zakonnik, pochodzący z Prus Wschodnich, który zdobył zaufanie wielu pracowników Stolicy Apostolskiej. Ordynariusz nie wyjawił jego nazwiska. Mógł on jednak interweniować w interesie diecezji warmińskiej w tamtejszych urzędach. Biskup Bludau odwołał się także do własnych doświadczeń. Przekonał się bowiem o antyniemieckim nastawieniu litewskiego duchowieństwa, kiedy zadecydował o wysłaniu sióstr zakonnych z Braniewa na Litwę. Litewscy księża odnosili się sceptycznie nawet do inicjatyw charytatywnych, jeśli prowadzili je Niemcy. Przedstawiciela delegatury apostolskiej na Litwie i w krajach bałtyckich abpa Antonia Zecchiniego ordynariusz warmiński uważał za przyjaznego Niemcom. Zecchini miał nawet z dystansem traktować biskupa żmudzkiego Franciszka Karewicza ${ }^{38}$.

W dalszej części rozmowy biskup zaznaczył, że parafie katolickie w Okręgu Kłajpedy erygowała diecezja warmińska i nadal będzie trzymała nad nimi swoją pieczę (,Wir haben die Gemeinden begründet und legen die Hand

${ }^{36}$ Ibidem, Konsulat Generalny Niemiec w Kłajpedzie do Ministerstwa Spraw Zagranicznych Niemiec, 14 V 1925, k. 225.

${ }^{37}$ Ibidem, k. 225-226. O konflikcie polsko-litewskim dotyczacym Wileńszczyzny zob. zwłaszcza: P. Łossowski, Das Wilna-Problem in der polnischen Außenpolitik 1918-1939, „Nordost-Archiv. Zeitschrift für Regionalgeschichte" (Neue Folge) 1993, t. II, z. 2, s. 279-298.

${ }^{38}$ BAB, R 5101/21807, Konsulat Generalny Niemiec w Kłajpedzie do Ministerstwa Spraw Zagranicznych Niemiec, 14 V 1925, k. 227. 
darauf'). Zgodził się również na przekazanie do Rzymu memoriału oraz na telegraficzne poinformowanie barona Cramer-Kletta o wyniku wizyty delegacji kłajpedzkiej we Fromborku. Ordynariusz podjął jeszcze gości w swoim pałacu ${ }^{39}$.

W odróżnieniu od wcześniejszych, niezbyt klarownych wypowiedzi biskupa warmińskiego co do statusu Kościoła katolickiego w Okręgu Kłajpedy, wspomniana delegacja nabrała przekonania, że lansuje on jego przynależność do diecezji warmińskiej. Niemiecki konsul w Kłajpedzie uzależniał jednak rokowania w tej sprawie od rzeczywistych wpływów barona Cramer-Kletta w Watykanie. Dyplomata przychylał się również do postulatu dziekana Dannelautzkiego, aby zrównać pensje duchowieństwa katolickiego z ewangelickim, które otrzymywało równowartość uposażenia pastorów zatrudnionych w Niemczech. Dotychczasowe działania wspomnianego dziekana, zmierzające do poprawy sytuacji materialnej duchowieństwa katolickiego, spotykały się ze sprzeciwem bądź obojętnością biskupa warmińskiego. Z kolei w czasie rozmowy z wicekonsulem Windeckerem ordynariusz warmiński poparł postulat dopłaty do pensji dla 6 katolickich duchownych Okręgu Kłajpedy z budżetu państwowego Niemiec ${ }^{40}$.

Tymczasem niewyjaśniony status granicznych obszarów Nadniemna przysparzał sporo problemów. Na początku listopada 1925 r. policja nadgraniczna przy nadprezydencie prowincji wschodniopruskiej relacjonowała, że księża z Litwy roztaczają opiekę duszpasterską nad katolicką ludnościa w powiecie Pogegen. Dotychczas sprawowali ja częściowo duszpasterze ze wschodniopruskiej Tylży. Biskup warmiński miał rzekomo sprzeciwić się działaniom Litwinów, wskazując, że Stolica Apostolska nie wyjaśniła jeszcze spornych kwestii odnoszących się do opisywanego obszaru ${ }^{41}$. Tegoż miesiąca niemieckie poselstwo w Kownie informowało o rokowaniach między Stolicą Apostolską a rządem Litwy dotyczacych konkordatu. Po opuszczeniu Kowna przez Zecchiniego działania dyplomatyczne w imieniu papieża podją dotychczasowy sekretarz arcybiskupa, protonotariusz Luigi Faidutti. On też wyjaśniał przedstawicielowi niemieckiej placówki dyplomatycznej w Kownie, że ponownie zainicjowano rozmowy o konkordacie z Litwa. Dotychczas odkładano je z powodu włączenia Wilna do struktur kościelnych w Polsce. Tym razem jednak prowadzono je niejawnie. Niemal pewny wydawał się podział Litwy na cztery diecezje: kowieńska, telszańska, mariampolską i koszedarska (skrawki obszarów wileńskich). Nie było jeszcze wiadome, czy zostanie utworzona prowincja kościelna na czele $\mathrm{z}$ arcybiskupem rezydujacym w Kownie ${ }^{42}$.

\footnotetext{
${ }^{39}$ Ibidem k. 227. Do barona Cramer-Kletta wysłano telegram o następującej treści: „Heute Bischof in Frauenburg gesprochen. Bischof unterstütz wärmstens unsere Wünsche und lässt Promemoria befürwortet Eure Adresse Rom abgehen”; zob. ibidem, k. 228.

${ }^{40}$ Ibidem, k. 228.

${ }^{41}$ Ibidem, policja nadgraniczna przy nadprezydencie Prus Wschodnich, 4 XI 1925, k. 234.

${ }^{42}$ Ibidem, poselstwo niemieckie w Kownie do Ministerstwa Spraw Zagranicznych Niemiec, 19 XI 1925, k. 240.
} 
Tegoż roku ks. Faidutti odwiedził Okręg Kłajpedy, aby osobiście przekonać się o sytuacji tamtejszego Kościoła katolickiego. Jego zdaniem inkorporacja tych obszarów do jednej z diecezji litewskich spotkałaby się z poważnymi trudnościami. Kulturowa różnica pomiędzy tą ludnością a mieszkańcami Litwy była dość znaczna. Ksiądz Faidutti odrzucał możliwość administrowania Krajem Kłajpedzkim przez inny ośrodek kościelny na Litwie, np. przez Telsze. Ten punkt widzenia zaprezentował władzom autonomicznego Kraju Kłajpedzkiego oraz bpowi Karewiczowi. Kościelne władze litewskie miały rzekomo wyrażać opinię, że wakaty duszpasterskie na opisywanym obszarze moga zostać obsadzone księżmi z Litwy. Przedstawiciel niemieckiego poselstwa w Kownie przekonywał ks. Faiduttiego, aby utrzymać zależność Kościoła katolickiego w Okręgu Kłajpedy od biskupa warmińskiego ze względu na wielowiekowe więzi Warmii z tym regionem. Proponował również, żeby jeszcze raz nakłonić hierarchę do interwencji w Watykanie ${ }^{43}$.

Jeszcze w 1925 r. wizytator apostolski abp Jerzy Matulewicz przybył do Kowna, aby przygotować podział i organizację Kościoła katolickiego na Litwie $^{44}$. Podkreślał przy tym stanowczo, że Kościół katolicki w Okręgu Kłajpedy zostanie oddzielony od diecezji warmińskiej i przyłączony do diecezji telszańskiej jako odrębny wikariat apostolski, na którego czele miał stać biskup telszański jako servatis servandis ${ }^{45}$. Na krótko przed ogłoszeniem bulli „Lituanorum gente” abp Matulewicz pisał do bpa Juozapasa Skvireckasa, że w przypadku Nadniemna musiał przezwyciężyć wiele problemów i utrudnień. Odpierał on przede wszystkim zarzuty i żądania formułowane przez władze niemieckie oraz biskupa warmińskiego. Konstatował, że na obszarze tym zostanie erygowana prałatura całkowicie związana z Litwa. Przyznał również, że nazwa „wikariat” była mniej korzystna ${ }^{46}$.

W połowie stycznia $1926 \mathrm{r}$. biskup warmiński ubolewał, że odwlekaja się pertraktacje dotyczące regulacji stosunków kościelnych na Litwie. Brano jednak w nich pod uwagę włączenie parafii katolickich Okręgu Kłajpedy do diecezji litewskiej. W tej sprawie ordynariusz warmiński interweniował u kardynała Sekretarza Stanu Stolicy Apostolskiej ${ }^{47}$, co spotkało się z uznaniem niemieckiego ministra nauki, sztuki i edukacji ${ }^{48}$. Miesiąc później podano do wiadomości, że abp Matulewicz zamierzał udać się do Rzymu, aby zrelacjonować Sekretariatowi Stanu postępy dotyczące przygotowania umowy konkordatowej z Litwą. Ksiądz Faidutti, którego uważano za bliskiego współpracownika abpa Matulewicza, twierdził, że toczące się rozmowy zostaną sfinalizowane w ciągu kilku miesięcy. Dwie ważne kwestie uniemożliwiały

\footnotetext{
${ }^{43}$ Ibidem, k. 240-240v.

${ }_{44}$ Ibidem, katolicka parafia w Tylży, 23 XII 1925, k. 242; A. Streikus, op. cit., s. 105.

${ }^{45}$ A. Streikus, op. cit., s. 106.

${ }^{46}$ Ibidem.

${ }_{47}$ BAB, R 5101/21807, bp Bludau do ministra nauki, sztuki i edukacji, 15 I 1926, k. 241.

${ }^{48}$ Ibidem, minister nauki, sztuki i edukacji do bpa Bludaua, 30 I 1926, k. 243.
} 
jednak ostateczne przypieczętowanie tej umowy. Dotyczyły one regulacji statusu Kościoła katolickiego w Okręgu Kłajpedy i nominacji nowych biskupów, w szczególności arcybiskupa Kowna. Litwini starali się o przyporządkowanie Okręgu Kłajpedy do litewskiej archidiecezji, natomiast Niemcy optowali za pozostawieniem tego obszaru w granicach diecezji warmińskiej. Ksiądz Faidutti zdawał się wykluczać obie opcje. Opowiadał się natomiast za kompromisowym rozwiązaniem, zgodnie z którym w Kraju Kłajpedzkim utworzono by szczególną jednostkę kościelną bezpośrednio podporządkowaną Stolicy Apostolskiej ${ }^{49}$. Z wypowiedzi Faiduttiego wynikało, że również abp Matulewicz przychylał się do tego rozwiązania ${ }^{50}$. Minister nauki, sztuki i edukacji konstatował, że wobec fiaska działań na rzecz utrzymania Okręgu Kłajpedy w granicach diecezji warmińskiej trzeba zagwarantować przynajmniej kształcenie niemieckich księży dla tego obszaru, którzy posługiwaliby się językiem litewskim. Nadzór nad edukacją tego duchowieństwa sprawowałby biskup warmiński ${ }^{51}$.

Status kościelny Okręgu Kłajpedy ujęto w bulli papieża Piusa XI „Lituanorum gente" z 4 IV 1926 r. Decyzja Stolicy Apostolskiej obszar ten został uniezależniony od diecezji warmińskiej. Nie udało się również utworzyć samodzielnej administratury kłajpedzkiej52. Biskup Bludau 26 V 1926 r. opublikował list na łamach „Pastoralblatt für die Diözese Ermland”, w którym ogłosił decyzję papieża dotycząca utworzenia udzielnej prałatury kłajpedzkiej (praelatura nullius). Wskazał przy tym, że wejdzie ona w życie w Niedzielę Trójcy Świętej, czyli 30 V 1926 r. Wierni oraz pracujaccy tam duchowni podlegali od tego czasu jurysdykcji nowego ordynariusza. Nowo utworzona prałatura składała się z 4 parafii należacych wcześniej do diecezji warmińskiej: Kłajpeda (Klaipėda), Szyłokarczma (Šilutè), Robkojen (Robkojai) i Wieszwile (Viešvilè) ${ }^{53}$.

Delegat papieski Faidutti wyjaśniał przedstawicielowi dyplomatycznemu Niemiec, że ze względu na prawo narodu litewskiego do niepodległości Rzym nie podporządkował Okręgu Kłajpedy bezpośrednio Stolicy Apostolskiej. Wybrano opcję zależności tego regionu od biskupa telszańskiego

${ }^{49}$ Ibidem, poselstwo niemieckie w Kownie do Ministerstwa Spraw Zagranicznych Niemiec, 19 II 1926, k. 280.

${ }^{50}$ Ibidem, k. 280-281.

${ }^{51}$ Ibidem, minister nauki, sztuki i edukacji do Ministerstwa Spraw Zagranicznych Niemiec, kwiecień 1926, k. 282.

${ }^{52}$ Ibidem, minister nauki, sztuki i edukacji do Ministerstwa Spraw Zagranicznych Niemiec, 31 V 1926, k. 283; zob. też: J. Ochmański, op. cit., s. 313; G. Adriányi, Geschichte der Kirche Osteuropas im 20. Jahrhundert, Paderborn 1992, s. 37.

${ }_{53}$ A. Kopiczko, Duchowieństwo katolickie..., s. 246-247; idem, Die katholische Kirche in Memelland..., s. 105; zob. też: Verordnungen des Bischöflichen Ordinariats. Abtrennung des Memelgebietes von der Diözese Ermland, „Pastoralblatt für die Diözese Ermland” 1926, nr 6, s. 157-158; Die Abtrennung des Memellandes von der Diözese Ermland. Eine Erinnerung an das Jahr 1926, „Ermländisches Kirchenblatt” 1939, nr 15, s. 214. 
(na ten urząd nominowano prałata Justinasa Staugaitisa), nadano jemu jednak charakter prałatury udzielnej. Związek pomiędzy diecezja Telsze a udzielną prałaturą kłajpedzką miała precyzować w przyszłości bulla papieska. Wybrano zatem rozwiąanie, które wprawdzie nie spełniało oczekiwań mieszkańców Okręgu Kłajpedy dotyczących całkowitej niezależności, ale również nie w pełni satysfakcjonowało stronę litewską dążącą do jego całkowitej inkorporacji ${ }^{54}$.

Przy okazji warto wspomnieć o diecezji telszańskiej oraz o jej ordynariuszu. Arūnas Streikus uważa, że nowy biskup telszański Staugaitis doskonale rozumiał kulturową i religijna specyfikę Okręgu Kłajpedy. Jako aktywny uczestnik życia politycznego niejednokrotnie wypowiadał się na temat tego regionu. Jeszcze przed objęciem swoich pastoralnych obowiązków w udzielnej prałaturze kłajpedzkiej wystosował list pasterski do tamtejszych katolików, w którym podkreślał, że nie przychodzi, aby likwidować miejscowe zwyczaje. Kościół katolicki, który jest jednością - konkludował ordynariusz - żąda najusilniej jedności we wszystkich istotnych rzeczach, jednak w drugorzędnych toleruje różnorodność i szanuje wieloletnie i wypróbowane zwyczaje, o ile nie przeciwstawiają się one zarządzeniom Kościoła ${ }^{55}$. W tamtym czasie do diecezji telszańskiej należało 308482 wiernych (do diecezji warmińskiej okragłe 340 tys.). Na jej obszarze nie było seminarium duchownego. Potencjalni kandydaci do kapłaństwa mieli kształcić się zatem w Kownie. Biskup warmiński zachował jednak pewne prerogatywy do Okręgu Kłajpedy. Dysponował on mianowicie prawem własności do domu dziecka i szkoły znajdujących się w Szyłokarczmie. Grunty ziemskie, na których były położone te budynki, należały do miejscowej parafii katolickiej. Zaproponowano zatem, aby utworzyć Towarzystwo Wychowawcze w Okręgu Kłajpedy (Erziehungsverein im Memellande), które wynajęłoby wspomniany ośrodek wychowawczy bądź kupiłoby ten obiekt ${ }^{56}$. Z kolei wschodniopruska parafia w Tylży rościła sobie prawo do kościoła i plebanii (obiekty złączone ze soba), a także do gruntów parafialnych w Wieszwile. Również niewielkie gospodarstwo rolne w Robkojen na skutek zapisu testamentalnego stało się własnościa parafii w Tylży. Należało się zatem spodziewać, że przypadnie ono wspólnocie katolickiej w Robkojen ${ }^{57}$. Niemieckie Ministerstwo Nauki, Sztuki i Edukacji sugerowało, aby w powyższych sprawach nie podejmować żadnych kroków prawnych, ale oczekiwać stosownej reakcji biskupa telszańskiego ${ }^{58}$.

${ }^{54}$ BAB, R 5101/21807, Ministerstwo Spraw Zagranicznych Niemiec do Ministerstwa Nauki, Sztuki i Edukacji, 23 IV 1926, k. 287-287v.

55 A. Streikus, op. cit., s. 106; zob. też: A. Kopiczko, Die katholische Kirche in Memelland..., s. 104.

${ }^{56}$ BAB, R 5101/21807, ks. Spannenkrebs do radcy ministerialnego Schlütera, 11 V 1926, k. 284.

${ }^{57}$ Ibidem, k. 284v.

${ }^{58}$ Ibidem, Ministerstwo Nauki, Sztuki i Edukacji do ks. Spannenkrebsa, 31 V 1926, k. 285. 
Uroczyste wprowadzenie bpa Staugaitisa do udzielnej prałatury kłajpedzkiej nastapiło 6 VI 1926 r. ${ }^{59}$ Ze względu na symboliczny charakter tej uroczystości warto poświęcić jej nieco miejsca. Na ten dzień kościół katolicki w Kłajpedzie przystrojono leśnym igliwiem. O godz. 10.00 biskup przyjechał samochodem z Krettingen. Po krótkiej ceremonii sekretarz biskupi przeczytał z ambony nominację papieską Staugaitisa na prałata kłajpedzkiego, najpierw po łacinie, następnie po litewsku, a na końcu po niemiecku. Przy stopniach ołtarza głównego ks. dziekan Dannelautzki przywitał dostojnego gościa w imieniu tamtejszej społeczności katolickiej. Następnie wspomniany biskup wygłosił przemowę z ambony. Później przeczytał jej tłumaczenie w języku niemieckim. W czasie uroczystej sumy pontyfikalnej asystowało ordynariuszowi liczne duchowieństwo. Uroczystość uświetnił katolicki chór pod przewodnictwem nauczyciela Nowatschina, wykonując mszę łacińską. Na jej zakończenie odśpiewano po niemiecku hymn Großer Gott, wir loben Dich. Po godzinie 13.00 na plebanii biskup przyjmował delegacje z gratulacjami ${ }^{60}$.

Urząd wikariusza generalnego udzielnej prałatury kłajpedzkiej powierzono Pranciškusowi Urbanavičiusowi (prałat papieski i prepozyt kapituły katedralnej w Telszach), oficjała - ks. Jurgisowi Narjauskasowi, zastępcy oficjała - ks. Antanasowi Krušy, promotora sprawiedliwości i obrońcy węzła małżeńskiego - ks. Pranciškusowi Bajerčiusowi (proboszczowi w Pogegen), sędziego - ks. Albertowi Dannelautzkiemu i ks. Juozasowi Ruibys-Rodavičiusowi (proboszcz w Robkojen), zarządcy dóbr kościelnych - Juozasowi Lechavičiusowi oraz konsultorów - ks. Franzowi Schachtowi (proboszczowi w Szyłokarczmie), ks. Pranciškusowi Bajerčiusowi i ks. Juozasowi Ruibys-Rodavičiusowi ${ }^{61}$.

\section{Zakończenie}

Zmiana przynależności politycznej Okręu Kłajpedy po I wojnie światowej wymagała określenia statusu Kościoła katolickiego na tym obszarze. Autonomia Nadniemna, respektowana przez wielkie mocarstwa, a następnie zagwarantowana przez Republikę Litewska jako część tego kraju, uniemożliwiała zachowanie tamtejszych placówek duszpasterskich w granicach diecezji warmińskiej. Początkowo zamierzano utworzyć wikariat apostolski w Okręgu Kłajpedy, a nawet odrębną diecezję. Ostatecznie papież Pius XI w bulli „Lituanorum gente” z 4 IV 1926 r. nadał Kościołowi katolickiemu na tym

\footnotetext{
${ }^{59}$ Ibidem, Konsulat Generalny Niemiec w Kłajpedzie do Ministerstwa Spraw Zagranicznych Niemiec, 11 VI 1926, k. 288.

${ }^{60}$ Die Einführung des Bischofs Staugaitis als Prälat des Memelgebiets, „Memeler Dampfboot”, 6 VI 1926, nr 130.

${ }^{61}$ A. Kopiczko, Die katholische Kirche in Memelland..., s. 110.
} 
obszarze status prałatury udzielnej, na której czele stanął biskup telszański. Nie spełniono zatem oczekiwań zazwyczaj niemieckojęzycznych katolików kłajpedzkich, którzy dążyli do uzyskania autonomii kościelnej, czyli bezpośredniego podporządkowania Stolicy Apostolskiej. Decyzja papieska z pewnościa nie spotkała się również z aprobatą litewskich katolików, którzy liczyli na pełną inkorporację parafii kłajpedzkich do jednej z diecezji litewskich.

\section{Streszczenie}

Zgodnie z postanowieniami traktatu wersalskiego Okręg Kłajpedy został wydzielony z Prus Wschodnich i powierzony pod zarząd wielkich mocarstw. W styczniu $1923 \mathrm{r}$. Litwini wywołali powstanie i zajęli ten obszar. Z kolei rok później stał się on suwerenną częścią Litwy na prawach autonomii. Zmieniająca się sytuacja polityczna Nadniemna zmuszała władze kościelne do rewizji statusu Kościoła katolickiego w tym regionie. Zarówno dyplomacja niemiecka, jak i biskup warmiński dążyli do utrzymania parafii Okręgu Kłajpedy w granicach diecezji warmińskiej. Rząd niemiecki uważał, że dotychczasowa przynależność kłajpedzkich placówek duszpasterskich umożliwi pielęgnowanie niemieckości wśród tamtejszej ludności. Tymczasem Litwini zamierzali podporządkować ten region diecezji litewskiej. Rozważano różne warianty statusu Kościoła katolickiego w Okręgu Kłajpedy, od delegatury podległej biskupowi warmińskiemu do utworzenia odrębnej diecezji z biskupem niemieckim na jej czele. Brano pod uwagę również erygowanie wikariatu apostolskiego w tym regionie. Ostatecznie papież Pius XI w bulli „Lituanorum gente” z 4 IV 1926 r. utworzył na tym obszarze udzielna prałaturę kłajpedzką. Na jej czele staną biskup telszański. Wybrano zatem kompromisowe rozwiązanie, które z pewnością nie satysfakcjonowało żadnej ze stron. Uroczyste objęcie rządów przez bpa Justinasa Staugaitisa w prałaturze odbyło się 6 czerwca tego roku.

\section{Negotiations on the Status of the Catholic Church in the Klaipeda District in 1923-1926}

In accordance with the provisions of the Treaty of Versailles, the Klaipeda District was separated from East Prussia and entrusted to the management of great powers. In January 1923, Lithuanians sparked off an uprising and took over the area. One year later it became a part of Lithuania with autonomy. The changing political situation of the Nemen region forced the Church authorities to review the status of the Catholic Church in this region. Both German diplomacy and the Warmian bishop sought to maintain the parishes of the Klaipeda District within the diocese of Warmia. The German government believed that the former affiliation of Klaipeda ecclesiastical institutions would made it possible to nurture the Germanness among the local population. Lithuanians on the other hand intended to subordinate this region to the Lithuanian diocese. Various variants of the status of the Catholic Church in the Klaipeda District were considered, from a delegacy subordinate to the Warmian bishop to the establishment of a separate diocese with the German bishop at its head. The erection of an apostolic vicariate in this region was also considered. Ultimately, Pope Pius XI by his bull Lituanorum gente of 4 April 1926 created a separate Klaipeda's prelature, with the bishop of Telsche at its head. Therefore, a compromise solution was chosen that certainly did not satisfy either party. The solemn assumption of office by Bishop Justinas Staugaitis took place on 6 June that year. 


\section{Bibliografia}

Adriányi G., Geschichte der Kirche Osteuropas im 20. Jahrhundert, Paderborn 1992.

Hermann A., Die Evangelische Kirche im Memelland des 20. Jahrhundert, „Nordost-Archiv. Zeitschrift für Regionalgeschichte” (Neue Folge) 2001, t. X, s. 337-367.

Kopiczko A., Die katholische Kirche in Memelland (1923-1939), „Acta Historica Universitatis Klaipedensis" 2015, t. XXX, s. 101-125.

Kopiczko A., Duchowieństwo katolickie diecezji warmińskiej w latach 1821-1945, cz. 1: Studium prozopograficzne, Olsztyn 2004.

Kurschat H.A., Das Buch vom Memelland. Heimatkunde eines deutschen Grenzlandes, Oldenburg 1968.

Łossowski P., Das Wilna-Problem in der polnischen Außenpolitik 1918-1939, „Nordost-Archiv. Zeitschrift für Regionalgeschichte" (Neue Folge) 1993, t. II, z. 2, s. 279-298.

Mikulicz S., Kłajpeda w polityce europejskiej 1918-1939, Warszawa 1976.

Ochmański J., Historia Litwy, wyd. 2 popr. i uzup., Wrocław 1982.

Streikus A., Die Integration der memelländischen Katholiken in die Kirchenprovinz Litauen 1926-1939, „Annaberger Annalen” 2013, nr 21, s. 100-127.

Tauber J., Das Memelgebiet (1919-1945) in der deutschen und litauischen Historiografie nach 1945, „Nordost-Archiv. Zeitschrift für Regionalgeschichte” (Neue Folge) 2001, t. X, s. 11-44.

Biog ra m: ks. Marek Jodkowski - dr nauk teologicznych w zakresie historii Kościoła, historyk sztuki i archiwista, adiunkt na Wydziale Teologii Uniwersytetu Warmińsko-Mazurskiego w Olsztynie. Zajmuje się dziejami Kościołów katolickiego i ewangelickiego w Prusach Wschodnich w XIX oraz pierwszej połowie XX w. E-mail: ksmarekj@wp.pl. 